\title{
Correction to: Thickening-upward cycles in deep-marine and deep-lacustrine turbidite lobes: examples from the Clare Basin and the Ordos Basin
}

\author{
Lei-Fu Zhang ${ }^{1,2,3,4^{*}}$ and Da-Zhong Dong ${ }^{1,3,4}$
}

\section{Correction to: Journal of Palaeogeography (2020) 9:11 https://doi.org/10.1186/s42501-020-00059-9}

Since the publication of our article (Zhang and Dong 2020) it has been brought to our attention that in the legend to Figure 9 we omitted to state that this figure is modified from Figure 5 of Macdonald et al. (2011) with permission of the Geological Society of London. We apologize to Macdonald et al. and to readers for any inconvenience caused.

\section{Author details}

${ }^{1}$ PetroChina Research Institute of Petroleum Exploration and Development, Beijing 100083, China. ${ }^{2}$ School of Geological Sciences, University College Dublin, Dublin 4, Ireland. ${ }^{3}$ National Energy Shale Gas Research (Experiment) Center, Langfang 065007, Hebei Province, China. ${ }^{4}$ CNPC Key Laboratory of Unconventional Oil and Gas, Langfang 065007, Hebei Province, China.

Published online: 26 November 2020

\section{References}

Macdonald, H.A., J. Peakall, P.B. Wignall, and J. Best. 2011. Sedimentation in deep-sea lobe-elements: Implications for the origin of thickeningupward sequences. Journal of the Geological Society 168 (2): 319-332.

Zhang, L., and D. Dong. 2020. Thickening-upward cycles in deep-marine and deep-lacustrine turbidite lobes: Examples from the Clare Basin and the Ordos Basin. Journal of Palaeogeography 9: $11 \mathrm{https}: / /$ doi.org/10. 1186/s42501-020-00059-9.

* Correspondence: zhangleifu@petrochina.com.cn

'PetroChina Research Institute of Petroleum Exploration and Development, Beijing 100083, China

${ }^{2}$ School of Geological Sciences, University College Dublin, Dublin 4, Ireland

Full list of author information is available at the end of the article

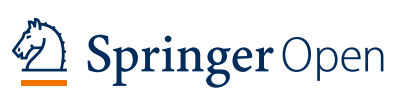

(c) The Author(s). 2020 Open Access This article is licensed under a Creative Commons Attribution 4.0 International License, which permits use, sharing, adaptation, distribution and reproduction in any medium or format, as long as you give appropriate credit to the original author(s) and the source, provide a link to the Creative Commons licence, and indicate if changes were made. The images or other third party material in this article are included in the article's Creative Commons licence, unless indicated otherwise in a credit line to the material. If material is not included in the article's Creative Commons licence and your intended use is not permitted by statutory regulation or exceeds the permitted use, you will need to obtain permission directly from the copyright holder. To view a copy of this licence, visit http://creativecommons.org/licenses/by/4.0/. 